\title{
The Dutch National System for forest sector greenhouse gas reporting under UNFCCC
}

\author{
G. J. Nabuurs · I. J. J. van den Wyngaert • \\ W. Daamen · H. Kramer · P. Kuikman
}

Received: 19 July 2006/Accepted: 16 March 2007/Published online: 5 May 2007

(C) Springer Science+Business Media B.V. 2007

\begin{abstract}
A full account for carbon dioxide $\left(\mathrm{CO}_{2}\right)$ and other greenhouse gas balance is presented for the Dutch forest and nature areas for 1990-2002 at a Tier 2.5 level. The paper outlines how complex guidelines can be turned into a practical system, appropriate for a small country, making use of the best knowledge and data available. The net total sink of all processes of the forest and other nature terrains balance is very stable through time around an average of 1.74 million tonnes of $\mathrm{CO}_{2}$ per year. The sink is to a large extent determined by the growth of forest remaining forest, and the harvest taking place in there. Newly added processes in this new National System are significant as well, but they compensate each other. The sources from deforestation and nitrous oxide $\left(\mathrm{N}_{2} \mathrm{O}\right)$ emissions (around 900 ktonne $\mathrm{CO}_{2}$ ) are for two thirds compensated by the sinks from afforestation, dead wood, soil $\mathrm{C}$ changes due to land use changes, and trees outside the forest. The land use changes between 1990 and 2000 showed that The Netherlands has an annual deforestation of 2504 ha ( $0.7 \%$ of the forest area) and an afforestation of 3124 ha. Deforestation led in total over the 13 years of 1990-2002 to an emission of 11.2 million tonne $\mathrm{CO}_{2}$ compensated by only 1.9 million tonne $\mathrm{CO}_{2}$ due to afforestation.
\end{abstract}

Keywords UNFCCC · Carbon sequestration · Deforestation · Netherlands · CO2FIX

\section{Introduction}

The Netherlands as a Party to the United Nations Framework Convention on Climate Change (UNFCCC) has the obligation to design and operationalise a national system (Article 5 of the UNFCCC) for the Land Use, Land-Use Change and Forestry sector

G. J. Nabuurs $(\bowtie)$ · I. J. J. van den Wyngaert · W. Daamen · H. Kramer · P. Kuikman Alterra, P. O. Box 47, 6700 Wageningen, Netherlands

e-mail: Gert-jan.nabuurs@wur.nl 
(LULUCF). One of the elements of such a system is an inventory system for greenhouse gases for the forest and nature land uses. Good Practice Guidance (GPG) for such an inventory, monitoring, and reporting system was prepared by the Intergovernmental Panel on Climate Change (IPCC 2003) and specifically deals with the forest sector as a single sector. Recently this guidance was improved and merged with the agriculture guidance into the IPCC 2006 Guidelines (IPCC 2006). Other types of nature (heath, wetlands, sand dunes, etc) are dealt with in the Guidelines as either grasslands, wetlands or other lands.

Up to the 2002 reporting year, the Netherlands reported only few activities to the UNFCCC under Category 5 (Spakman et al. 1997; Olivier et al. 2003; Klein Goldewijk et al. 2004). These are the carbon (C) sinks from changes in forest biomass (Category 5A), and the nitrous oxide $\left(\mathrm{N}_{2} \mathrm{O}\right)$ and methane $\left(\mathrm{CH}_{4}\right)$ emissions from agricultural soils (Category $5 \mathrm{E}$ ). For the first category, only one average increment rate of forests was multiplied with biomass expansion factors for deciduous and coniferous forests. It was clear that this level of reporting would not suffice the new requirements in which countries are requested to report as accurately as can reasonably be expected from them (Kuikman et al. 2004).

Here we describe the approaches, methods, data and results for the Dutch National System for forest and nature areas. The main aim of the paper is to point at how the complex guidelines can be turned into a practical system. This system should yield results at an accuracy level that can reasonably be expected from a small forest country in which forests are not a key category. How to do this, realising that for a small forest country some of the problems are the same as for a big forest country, is the centre of attention here.

\section{Approach used for the national System for forest and nature area}

For the year 2000 The Netherlands reported a sink of 1.4 Mton carbon dioxide $\left(\mathrm{CO}_{2}\right)$ for category 5A ('Changes in Forest and other Woody Biomass Stocks') (Klein Goldewijk et al. 2004). Out of the total national emissions reported for that year (169.3 Mton $\mathrm{CO}_{2}$ ), the sink comprised $0.8 \%$. This, nor the strong fluctuations between years, would justify it to make the forest sector a Key Category. ${ }^{1}$ Therefore the forest sector was reported based on IPCC defaults methods and data, whereby one nationally derived stem increment was converted to whole tree biomass based on one IPCC biomass expansion factor.

However, a couple of reasons arose that require elaboration of the work for the forest sector reporting:

- Requirements as described by the Marrakesh Accords to set up a National System;

- Additional reporting requirements for Kyoto lands starting as of 2008;

- Existence of a detailed and ongoing geo-referenced forest inventory system;

- Reviews of Category 5A from National Communications made by the UNFCCC secretariat stating that many Parties report this category in a poor way and lack almost all background material (UNFCCC 2004) (FCCC/SBSTA/2004/INF.7);

- The Netherlands has one of the more intensively managed biospheres in the world;

- The whole land use sector (incl. livestock) in the Netherlands comprises a significant share of the total emissions with respectively $13 \%, 55 \%$ and $42 \%$ of total emissions of $\mathrm{CO}_{2}, \mathrm{~N}_{2} \mathrm{O}$, and $\mathrm{CH}_{4}$;

\footnotetext{
${ }^{1}$ Key category's: A category that is prioritized within the national inventory system because its estimate has a significant influence on a country's total inventory of direct greenhouse gases in terms of the absolute level of emissions, the trend in emissions, or both.
} 
- The obligation to report as accurately as can reasonably be expected from a country;

- The political sensitivity of this category in international negotiations.

These items together were reason for the Netherlands to decide to report the forest carbon stock changes from now on ${ }^{2}$ at Tier 2.5 level. Tier 2.5 applies the same basic approach as Tier 1 (stock change) but applies detailed emission factors and activity data which are defined by country specific data for the most important land uses and activities. Higher resolution activity data are typically used in Tier 2.5 to correspond with countrydefined coefficients for specific regions and specialised land use categories (IPCC 2003). In comparison to a Tier 3 method, the current system mainly lacks a full dynamic and a full geographically explicit approach. However on the most important pools (living biomass of forest remaining forest), the approach is clearly a Tier 3.

The approach chosen follows the IPCC GPG. Namely a carbon stock change approach based on inventory data subdivided to appropriate pools and land use types. The pools distinguished are aboveground biomass, belowground biomass, dead wood, litter, and soil organic carbon. For litter and soil organic carbon in 'forest remaining forest' and for biomass in other nature terrains it is assumed that the stock does not change. Therefore no sink is calculated, only the present stock.

In short the Dutch National System consists of land use maps combined with a wide variety of databases. Some of these databases rely on ongoing monitoring, some are based on former monitoring results or derived from literature (Fig. 1).

The basis is formed by the land use maps for 1990 and 2000. Out of these, the land use change matrix is derived from a comparison of a gridded version of these maps (Kramer and Knol 2007). For 'Forest remaining Forest' the land use is combined with the national forest inventory database (MFV for 2000 and HOSP for 1990), whose stemvolume data are converted to whole tree carbon through selection of allometric equations from a large European equation and biomass database (see details in Sect. 3).

For 'Other lands converted to Forest' a rather simple calculation is carried out that assesses the losses or gains of biomass per transition. For these areas that fall under a transition a simple soil $\mathrm{C}$ balance is assessed. Additional sources of information are used for other nature terrains, soil organic carbon, litter, non $\mathrm{CO}_{2}$ gases, and wood products.

\section{Methods and data for area determination}

\subsection{Introduction}

From Nabuurs et al. (2003) it appeared that several methods for forest area assessment for the Netherlands had been applied in the past (Fig. 2), all yielding different results, with up to $18 \%$ difference. Nevertheless, estimates seem to be converging around 360,000 ha. It was concluded that the most accurate assessment is based on the topographical maps. The approach was therefore to derive a land use and land use change matrix from topographical maps of 1990 and 2000 (Kramer and Knol 2007). So, forest and nature area determination according to approach 3 as described in Good Practice Guidance (IPCC 2003, p. 2.12), was applied.

However, the 1990 map was available only as hard copy. Therefore, following procedure was applied: digital scans of the 1990 maps were made, resulting in gridded maps

\footnotetext{
${ }^{2}$ NIR 2005, covering up to the year of 2002 .
} 


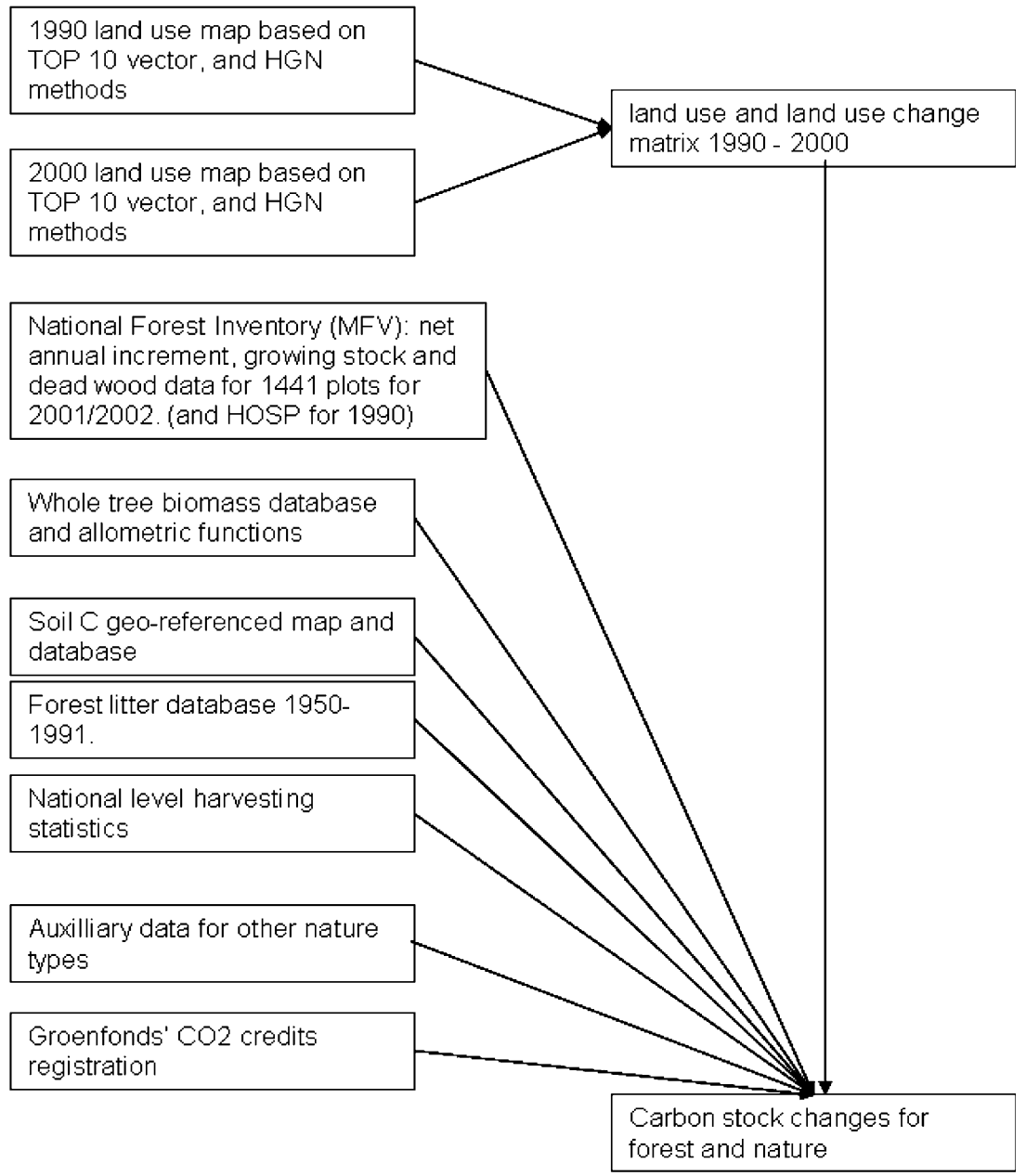

Fig. 1 Set up of the Dutch National System for greenhouse gas reporting of forest and nature areas

with a resolution of $2.5 \times 2.5 \mathrm{~m}$. These were aggregated to $25 \times 25 \mathrm{~m}$ grids. The 2000 map was already available in $25 \times 25$ m grids. These maps were overlaid. However, both of these maps held small methodological differences and colour differences used in the hard copy maps. These were corrected for (Kramer and Knol 2007). Based on criteria, definitions, and preferred land use classes, the final runs were made to derive and classify the digital maps. It was important to be able to distinguish forest according to the national forest definition, and therefore a sub class 'Forest according to forest definition' ${ }^{3}$ was defined (Table 1). In practice it meant that if a minimum of 8 cells of forest were connected, then this was regarded as forest according to the definition.

\footnotetext{
${ }^{3}$ Dutch forest definition: minimum of $0.5 \mathrm{ha}$, width of patch minimum $30 \mathrm{~m}$, minimum height of trees $5 \mathrm{~m}$, crown cover minimum of $20 \%$.
} 


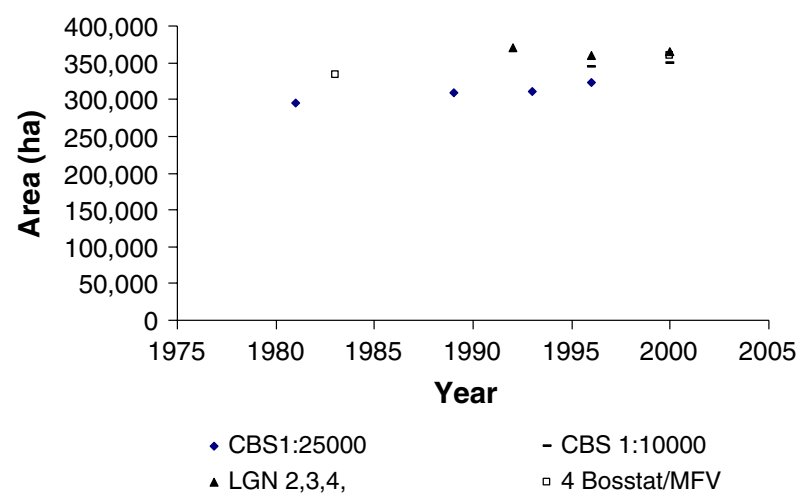

Fig. 2 Estimates for forest area in The Netherlands based on various sources. 'LGN' are satellite derived data, 'CBS' is the Dutch statistical bureau represented here by estimates based on two scales of maps. ' 4 bosstat' is the area statistic for the fourth Dutch forest statistic carried out in 1983, and 'MFV' is the latest forest map based on a polygon conversion of the 1:10,000 topographical maps. For the Dutch National System (current report) a methodology comparable to the 'MFV' was used

Table 1 Land use classes as defined in the maps used for the Dutch National System (HGN maps) and the equivalent land use class in Good Practice Guidance

\begin{tabular}{lll}
\hline HGN Basis & HGN sub division & GPG classes \\
\hline Forest & Forest according to forest definition & Forest \\
& Trees outside the forest & Forest \\
Grassland & & Forest \\
Cropland/bare soil & & Grassland \\
Settlement & Settlement & Cropland \\
Water & Road & Settlement \\
Reed swamp & & Settlement \\
Sand & & Not terrestrial \\
& Bare coastal dune & Wetland \\
& Beach & Other \\
\hline
\end{tabular}

\section{Methods and data for forest biomass and dead wood stock changes}

4.1 Carbon balance of living biomass in 'Forest remaining forest'

\subsubsection{Basic data}

The basic approach follows the IPCC GPG for Land Use, Land Use Change and Forestry where a stock change approach is suggested. The basic assumption is that the net flux can be derived from converting the change in growing stock volume in the forest to carbon. Either as basic data the stock at two points in time is known, or the stock at one point is known plus the increment in consecutive years. 
Calculations for the living biomass carbon balance are carried out at the plot level. The Dutch National Forest Inventory has been used for this. This was available for two periods: (a) 1988-1992, the so-called HOSP data, and (b) 2001-2002, the MFV data. HOSP plot level data (2007 plots $\sim 400$ plots per year) for growing stock volume, increment, age, tree species, height, tree number and dead wood were used for the 1990 situation. Forward calculation with these data was applied to the year 1999. MFV plot level data for growing stock volume, increment, age, tree species, height, tree number and dead wood were used from there on. In total 1440 plot recordings with forest cover were available for the years 2001 and 2002. MFV continued in 2004 as well with another 900 plots, with litter layer thickness as well. MFV data were used as one set of data; i.e. the resulting carbon balance is applied to the year 2000, 2001 and 2002.

\subsubsection{Additional data}

Harvesting levels were recorded in the HOSP inventory, so they were available by plot, but to arrive at national totals, these field data are complemented with questionnaires to owners, and industry. Therefore total harvesting levels as given in Table 2 were used.

The national level harvest was assigned to plots as thinnings based on criteria that plots may meet. The criteria are: age $>110$, or growing stock more than $300 \mathrm{~m}^{3} \mathrm{ha}^{-1}$. If a plot meets these criteria, a thinning of $9 \%$ of the volume was carried out in the plot. No clearcuts were carried out. This was done for several reasons: (1) clearcuts are hardly carried out anymore in the Netherlands, (2) carrying out forward calculation with hypothetical clearcuts with no information of regeneration type from the single inventory cycles leads to highly uncertain forest development. Therefore it was decided to carry out the forward calculations with thinnings only.

To convert stemwood volume to whole tree biomass, basic wood density values as given in Nabuurs et al. (2005) were used. For the next conversion step to whole tree biomass, we relied on the COST E21 database on biomass equations (Zianis et al. 2005). For validation and choice of the equation we made use of the biomass database collected by Van Hees A. F. M. (personal communication). So, the model does not dynamically calculate branch and root growth, but calculates the volume of the stem in year $t+1$, and then converts the growing stock to whole tree biomass with the biomass expansion factors suitable to convert stocks.

Table 2 National level wood production data

\begin{tabular}{cllc}
\hline Year & $\begin{array}{l}\text { Fellings } \\
\left(1000 \mathrm{~m}^{3} \mathrm{year}^{-1}\right)\end{array}$ & Type of felling & Reference \\
\hline 1990 & 313 & Final cut & $\begin{array}{c}\text { Daamen } \\
1991\end{array}$ \\
$1990-$ & 1196 & Thinning & Daamen \\
1994 & & Thinning and final cut from production forest plus outgrown & 1994 \\
$1991-$ & 1568 & coppice, and other & 1996 \\
1995 & & production forest plus outgrown coppice, and other & Daamen \\
$1992-$ & 1339 & production forest plus outgrown coppice, and other & 1997 \\
1996 & & & Daamen \\
$1993-$ & 1455 & HOSP forest plus additional forest & 1998 \\
1997 & & & Daamen \\
$1995-$ & 1397 & & 2000 \\
1999 & & &
\end{tabular}




\subsubsection{Calculation method}

To forward calculate standing volume at the plot level, the plot level data for specific year were combined with Dutch growth and yield functions. The resulting net flux (NEP, because it is assumed that all litter decomposes the same year) is derived from the tree mass at time $t$ and $t+1$, the basic wood density and the carbon content of dry mass (50\%). For further details see Nabuurs et al. (2005).

$$
\Delta C(\text { trees })_{\text {plot }}=\frac{\left(M_{\text {tree }}(t)-M_{\text {tree }}(t+1)\right)}{\Delta t} \times N_{\text {trees }} \times F_{\text {carbon }}
$$

with $\Delta C$ (trees) $)_{\text {plot }}$ is the net $C$ flux in living biomass per plot $\left(\mathrm{kg} \mathrm{C} \mathrm{ha}^{-1}\right.$ years $\left.{ }^{-1}\right) ; M_{\text {tree }}(t)$ the total tree biomass at time $t(\mathrm{~kg} \mathrm{DW}) ; N_{\text {trees }}$ the number of trees $\left(\mathrm{ha}^{-1}\right) ; F_{\text {carbon }}$ the carbon content ( $\left.\mathrm{kg} \mathrm{C} \mathrm{kg}^{-1} \mathrm{DW}\right) ; \Delta t$ the time between $t$ and $t+1$ (year).

The net $C$ flux to dead wood is the remainder of the input of dead wood due to mortality minus the decay of dead wood. It is reasonable to believe that a net build up may exist, because Dutch forestry is allowing dead wood to accumulate only since one decade. The mortality rate was assumed to be a fixed fraction of the standing volume $\left(0.4 \%\right.$ year $\left.^{-1}\right)$. MFV data provide a current stock of dead wood volume (both lying and standing) of $6.6 \%$ of the living wood volume.

The decay of dead wood is determined by the total time needed to fully decompose (Hees and Clerkx 1999). The wood density varies strongly during this decomposition, but was assumed to be $50 \%$ of the basic wood density of the living trees.

$$
\begin{aligned}
\Delta C(\text { deadwood })_{\text {plot }} & =\text { Out } C(\text { deadwood })_{\text {plot }}-\operatorname{In} C(\text { deadwood })_{\text {plot }} \\
\text { InC(deadwood })_{\text {plot }} & =M_{\text {tree }}(t) \times N_{\text {trees }} \times F_{\text {carbon }} \times F_{\text {mortality }} \\
\text { Out } C(\text { deadwood })_{\text {plot }} & =\left(\frac{V_{\text {Dead } \_}}{T B P_{\mathrm{S}}}+\frac{V_{\text {Dead } \_\mathrm{L}}}{T B P_{\mathrm{L}}}\right) \times W D_{\text {Dead }} \times F_{\text {carbon }}
\end{aligned}
$$

where $\Delta C$ (deadwood $)_{\text {plot }}$ is the $C$ change in dead wood per plot $\left(\mathrm{kg} \mathrm{C} \mathrm{ha}^{-1}\right.$ year $\left.^{-1}\right)$; In$C$ (deadwood) $)_{\text {plot }}$ and Out $C$ (deadwood) $)_{\text {plot }}$ the input and loss per plot $\left(\mathrm{kg} \mathrm{C}^{-1} \mathrm{haar}^{-1}\right)$; $\Delta C$ (trees) $)_{\text {plot }}$ the net $C$ flux per plot $\left(\mathrm{kg} \mathrm{C} \mathrm{ha}^{-1}\right.$ year $\left.^{-1}\right) ; M_{\text {tree }}(t)$ the total tree biomass at time $t(\mathrm{~kg} \mathrm{DW}) ; N_{\text {trees }}$ the number of trees $\left(\mathrm{ha}^{-1}\right) ; F_{\text {carbon }}$ the carbon content $\left(\mathrm{kg} \mathrm{C} \mathrm{kg}^{-1}\right.$ DW); $F_{\text {mortality }}$ the mortality $\left(\right.$ year $^{-1}$ ); $V_{\text {Dead } \_S, L}$ the volume of standing resp. lying dead wood; $T B P_{\mathrm{S}, \mathrm{L}}$ period for total decay of dead wood, standing and lying; $W D_{\text {Dead }}$ the density of dead wood.

To derive a national total, the representativity of each plot was used. These are given by the inventory data.

\subsection{Carbon balance of living biomass when land use changes}

During land use changes large pulses of emissions can occur. Then afterwards, the total carbon system and especially soils adapt to the new situation where there may be less or more litter input to the soil then in the previous situation. The IPCC (2003) gives a default period of 20 years for the soil to reach an equilibrium again with the litter input. However, IPCC also notes that this is a relatively short period, but chosen because of its practicability.

Here we followed a static approach to quantify the carbon implications of land use changes. Non- $\mathrm{CO}_{2}$ emissions related to deforestation are assumed negligible. The static 
Table 3 Compilation of published $\mathrm{N}_{2} \mathrm{O}$-emission rates from soils of temperate forest ecosystems, aggregated into forest types from Papen and Butterbach-Bahl (1999)

\begin{tabular}{|c|c|}
\hline & $\begin{array}{l}\text { Mean annual flux } \\
\left(\mathrm{kg} \mathrm{N}_{2} \mathrm{O}-\mathrm{N} \text { ha }^{-1} \text { year }^{-1}\right)\end{array}$ \\
\hline Spruce & +0.1 to +2.2 \\
\hline Douglas fir & +0.1 to +0.7 \\
\hline Pine & +0.01 to +0.4 \\
\hline Beech & +0.4 to +7.8 \\
\hline Mixed oak- beech etc. & +0.02 to +0.9 \\
\hline
\end{tabular}

approach implies that at the time of e.g. deforestation it is assumed that the total carbon stock in living biomass is lost in the same year (on average 71 tonne $\mathrm{C} \mathrm{ha}^{-1}$ ). Always the average carbon stock is used, as the sampling density of the national inventory was not dense enough to assess the actual carbon stock of each deforested lot.

For afforestations it was assumed that half of the carbon uptake factor for the existing forest applies, i.e. $1.4 \mathrm{Mg} \mathrm{C} \mathrm{ha}^{-1}$ year $^{-1}$. This was the only reasonable assumption as specific data of each afforested lot were not available.

For soils it is assumed that the average carbon stock in the soil under the previous land use type changes to the average carbon stock in the new land use in the same year (see chapter 5, Kuikman et al. 2003). This is assumed to give the same result as following each plot dynamically in time. Furthermore, the soils database was not geographically explicit enough to accurately derive the soil carbon stock at the specific site where the land use change took place.

\section{3 $\mathrm{CH}_{4}, \mathrm{~N}_{2} \mathrm{O}$ and other GHG's balance in forest remaining forest}

\subsection{1 $\mathrm{N}_{2} \mathrm{O}$}

$\mathrm{N}_{2} \mathrm{O}$ emissions occur through a variety of nitrogen related processes in forest soils (Lindner et al. 2004). They are further modified through $\mathrm{N}$ deposition, fertilization and other human induced forest management acts. Table 3 gives an overview of some measurements. The variety in $\mathrm{N}_{2} \mathrm{O}$ emissions is large, both in time and space.

Taking into account that approximately $40 \%$ of the Dutch forests consists of Scots pine, $10 \%$ spruce, $10 \%$ Douglas fir. $20 \%$ beech and the rest may resemble the mixed oak beech forest of the Table 3 above, we come to an average $\mathrm{N}_{2} \mathrm{O}-\mathrm{N}$ emission for the Dutch forests of $0.229 \mathrm{~kg} \mathrm{~N}_{2} \mathrm{O}-\mathrm{N}$ ha $^{-1}$ year $^{-1}$. This totals an emission of $82584 \mathrm{~kg} \mathrm{~N}_{2} \mathrm{O}-\mathrm{N}^{4}$ year $^{-1}$ or 25.6 ktonne $\mathrm{CO}_{2}$ eq. Since this first estimate yields a very small number, and since deliberate fertilization of forests is not occurring in The Netherlands, no further action to refine this was taken.

\subsection{2 $\mathrm{CH}_{4}$}

It is widely believed that well aerated forest soils are sinks for atmospheric $\mathrm{CH}_{4}$ whereas water saturated forest soils such as gley soils, riparian forest soils or forested bogs and fens can also be significant sources of $\mathrm{CH}_{4}$ (IPCC 2003; Lindner et al. 2004). Although Lindner et al. (2004) provide a European average sink of methane of $-0.2 \mathrm{~kg} \mathrm{CH}_{4}$ ha $^{-1}$ year $^{-1}$, the

\footnotetext{
${ }^{4} \mathrm{GWP}$ of $\mathrm{N}_{2} \mathrm{O}=310$.
} 
uncertainty around this mean is too large to give an estimate for Dutch forest with any certainty. Since this first estimate yields a very small number, and since hardly any Dutch measurements are available for The Netherlands, no further action to refine this was taken.

\subsubsection{Other GHG's}

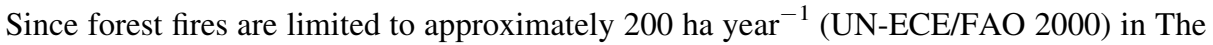
Netherlands annually, it was assumed that $\mathrm{CO}, \mathrm{NO}_{x}$, and $\mathrm{VOC}$ emissions are negligible.

\subsection{Biomass data for other nature terrains}

Other nature terrains in The Netherlands consist mainly of trees outside the forest, heathland, inland sand dunes, coastal dunes, swamp and peat areas. It is assumed that in all of these terrains the living biomass carbon stock does not change. For heathland an average carbon stock in living biomass of 8 tonne $\mathrm{C} \mathrm{ha}^{-1}$ is a good estimate (Diemont and Oude Voshaar 1994). For swamp and peat areas we only assess the carbon stock in the soil organic matter following Kuikman et al. (2003). For trees outside the forest, permanent crops, vineyards, orchards etc we follow the previous National Inventory Reports (NIR) where a change in stock was assumed to occur only if an area change occurs. We thus copy the results of these NIR reports.

\subsection{Wood products}

For wood products it is assumed that they decompose in the same year as harvesting, i.e. no net build up of carbon in wood products in use is assumed. Neither is import or export of products taken into account. Since no international agreement has been reached on how to report wood products, this is a political decision to report in this way. Previous studies report a significant sink or source of wood products in the Netherlands (as a large importer) depending on the accounting methodology of the import and export.

\section{Methods and data for soil carbon stock changes}

\subsection{Forest remaining forest}

A variety of sources was investigated. Kuikman et al. (2003) give a good overview of available databases and come up with a geographically explicit soil C map for the Netherlands overlain on the LGN3 land use map. In addition the soil analysis database of Van den Burg (1999) was investigated. ICP litter and mineral soil data were used by Kuikman et al. (2003) and were therefore already incorporated in their analysis.

We assume that carbon stocks of soil organic carbon in mineral soil and in litter do not change over the time period analysed here, this is probably not the case as most forests are rather young, and were planted on degraded sites. Insufficient data are available to change this assumption into a reliable sink or source estimate. Therefore, for land uses that remain the same we only give a stock assessment of soil organic carbon that is actually a copy of Kuikman et al. (2003). For litter we applied the equations as given by Van den Burg (1999) to the MFV plots, this yields an average litter stock of 37 tonne $\mathrm{C} \mathrm{ha}^{-1}$. 
For losses of carbon from drained peatlands, Kuikman et al. (2003) give a national total of 4.8-7 million tonnes $\mathrm{CO}_{2}$ per year. However, they acknowledge that this is a rough estimate only, where by far most of the emissions occur in peat soils in agricultural use. Even the available estimates of peat area vary between 294,000 and 450,000 ha. These differences are partly caused by methodological problems, but also by actual changes in area of peat soils through time. Pleijter (2004) showed that in a case area, the area of peat soils decreased by $47 \%$ between 1980 and 2003. Given these uncertainties, and the fact that only $5.8 \%$ of the forests is situated on peat soils, we do not estimate the loss of carbon from drained peatland soils.

\subsection{Other land uses converted to and from forest}

For soil C stock changes due to land use changes de Groot et al (2005) combined the land use changes map as derived here (chapter 3) with the soil C map of Kuikman et al. (2003). Results are given in Sect. 6.

\section{Results for the forest sector carbon balance 1990-2002}

\subsection{Forest remaining forest}

A visualization of sources and sinks (NBP) per MFV plot for 2000 is given in Fig. 3. A large variation in space is clearly visible. This variation in space is also translated into a strong variation between years per plot. Where a harvest takes place in 1 year, a regrowth will occur the next year.

The results for 'forest remaining forest' show a very stable sink in the Dutch forest (Fig. 5). The average sink from growth of live trees lies around 3.9 million tonnes $\mathrm{CO}_{2}$ with a standard deviation of only 65 ktonne. Harvesting fluctuates a bit more, but gives an average emission of 2 million tonnes $\mathrm{CO}_{2}$ with a variation of 134 ktonne.

\subsection{Land use changes}

The land use change matrix with gross transitions between classes is given in Table 4 for 1990-2000. The calculations for the national system have been carried out with these gross changes. The tables show that in The Netherlands land use changes are significant. In total 642,000 ha have changed land use between 1990 and 2000; which is 15\% of the land! One third of these changes are between cropland and grassland, whereby grassland loses in total 113,000 ha. However, also concerning forests, the changes are quite large: The Netherlands deforests annually 2504 ha $\left(0.7 \%\right.$ year $\left.^{-1}\right)$, and afforests 3124 ha. Figure 4 gives a regional example where these changes in land use take place.

By combining standing biomass estimates with deforested area, the emission as given in Fig. 5 was derived. Deforestation in the Netherlands leads to an annual emission of 865 ktonne $\mathrm{CO}_{2}$ year $^{-1}$. Deforestation led in total over the 13 years of 1990-2002 to an emission of 11.2 million tonne $\mathrm{CO}_{2}$. The sink due to afforestation gradually increases as the area of afforestation increases, and led in total over 1990-2002 to a sink of 1.9 million tonne $\mathrm{CO}_{2}$.

\footnotetext{
${ }_{5}$ Kuikman et al. 2003 give $4.2 \%$ (p. 21 ) of $73 \%$ of the total forest: this equals $5.8 \%$ of the total forest.
} 


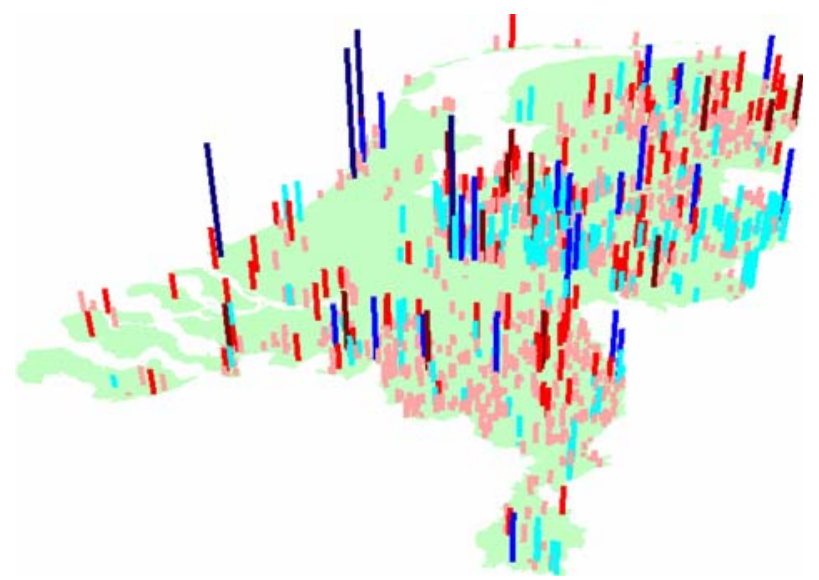

Fig. 3 Net flux (NBP) as assessed for each MFV data point for 'Forest remaining Forest' (blue = source due to harvesting, red = sink). This 3D map is a visualization of the spatial distribution of sinks and sources. The tallest blue bars represent an emission of some 7 tonne $\mathrm{C} \mathrm{ha}^{-1}$ year $^{-1}$ in stands that have recently been thinned

\subsection{Soil C stock changes under land use changes}

After a land use change, the soil carbon pool will gradually reach a new equilibrium with the input of litter that accompanies that land use. This process may take decades to centuries. Here we have assumed that we can sum these changes in soil $\mathrm{C}$ to the same year as when the land use change takes place. Regarding the forest and other nature terrains only, we derived an annual sink of 18.3 ktonne $\mathrm{CO}_{2}$ year ${ }^{-1}$ for the soil $\mathrm{C}$ changes. An average $\mathrm{N}_{2} \mathrm{O}-\mathrm{N}$ emission for the Dutch forests of $0.229 \mathrm{~kg} \mathrm{~N}_{2} \mathrm{O}-\mathrm{N}$ ha ${ }^{-1}$ year ${ }^{-1}$ was derived from literature. This totals an emission of $82584 \mathrm{~kg} \mathrm{~N}_{2} \mathrm{O}-\mathrm{N}^{6}$ year $^{-1}$ or 25.6 ktonne $\mathrm{CO}_{2}$ eq.

\subsection{Other nature terrains and trees outside the forest}

The results of the NIR 2004 was copied. However, the estimate for the stock assessment of trees outside the forest might be different from the previous NIR reports, as the area estimate differs now ( 22 kha now versus $10 \mathrm{kha}$ ). No new estimate was made, as the uncertainty is too high, and as a stock assessment is not required. The previous NIR gave an uptake of 209 ktonne $\mathrm{CO}_{2}$ per year.

\subsection{Total balance}

The net sink of the forest and other nature terrains balance is very stable around an average of 1.74 million tonnes of $\mathrm{CO}_{2}$ per year with a yearly variation of $88 \mathrm{ktonne}$. The sink is to a large extent determined by the growth of forest remaining forest, and the harvest taking place in there. Newly added processes in this new National System are significant as well, but they compensate each other. The sources from deforestation and $\mathrm{N}_{2} \mathrm{O}$ emissions

${ }^{6}$ GWP of $\mathrm{N}_{2} \mathrm{O}=310$. 


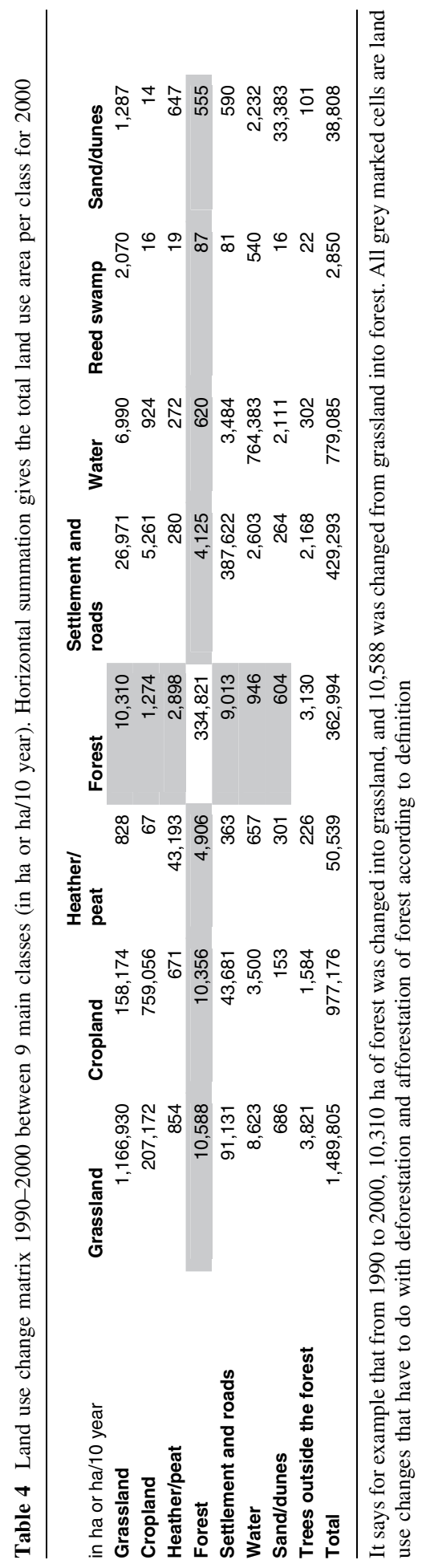



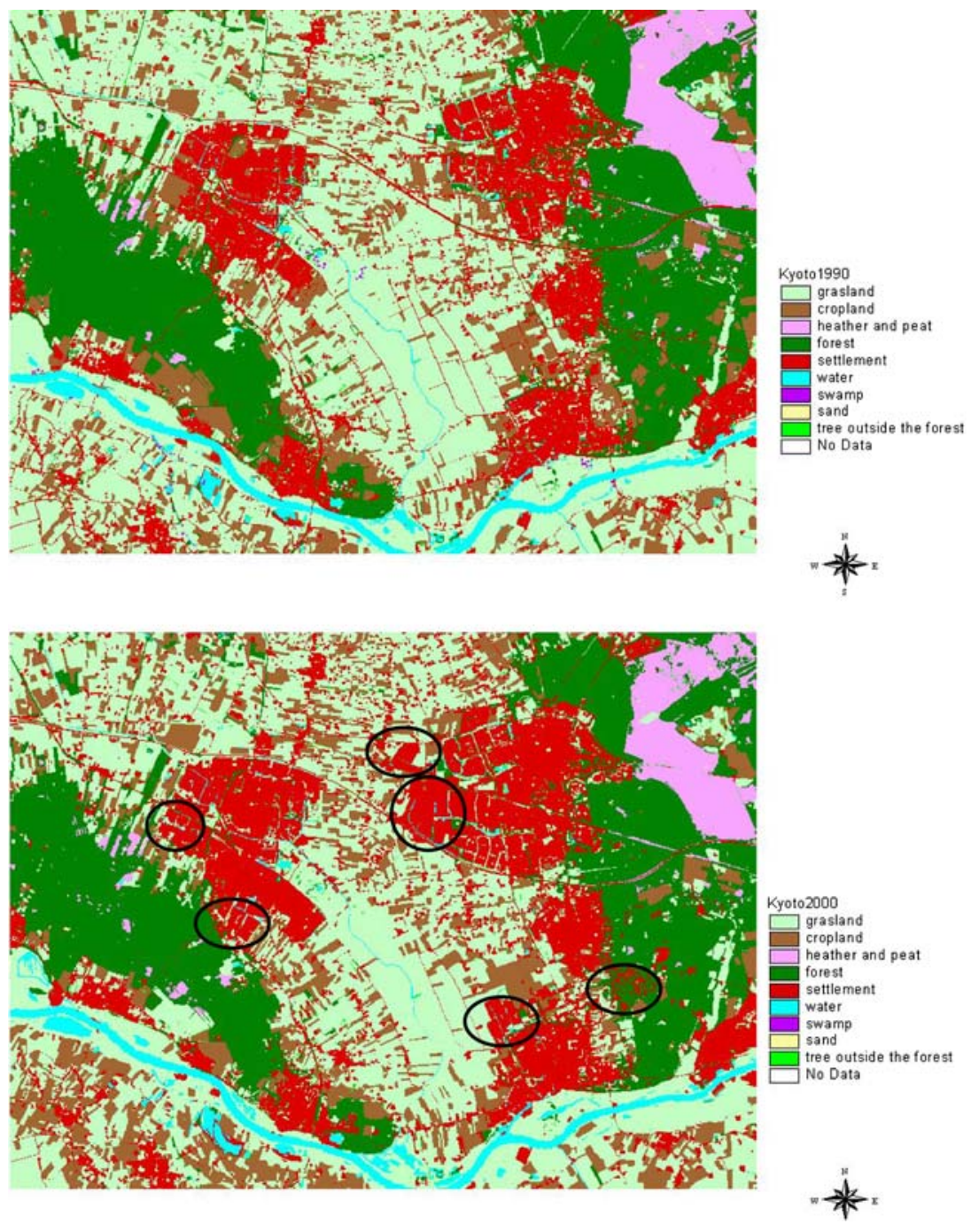

Fig. 4 Example area of the land use pattern in 1990 (top) and 2000 (bottom). Large settlement expansions (circles) are visible as well as a scattered increase of cropland at the expense of grassland. The shown area measures some 20 by $15 \mathrm{~km}$

(around 900 ktonne $\mathrm{CO}_{2}$ ) are for two thirds compensated by the sinks from afforestation, dead wood, soil $\mathrm{C}$ changes, and trees outside forest.

\section{Discussion and conclusions}

The current National System for forests is a significant expansion and improvement of the previous reporting done by The Netherlands. Now, all main pools and processes are followed for all forest and other nature terrains. Based on the new system a larger sink was found: on average a sink of 1.74 milllion tonnes $\mathrm{CO}_{2}$ was assessed compared to on average 


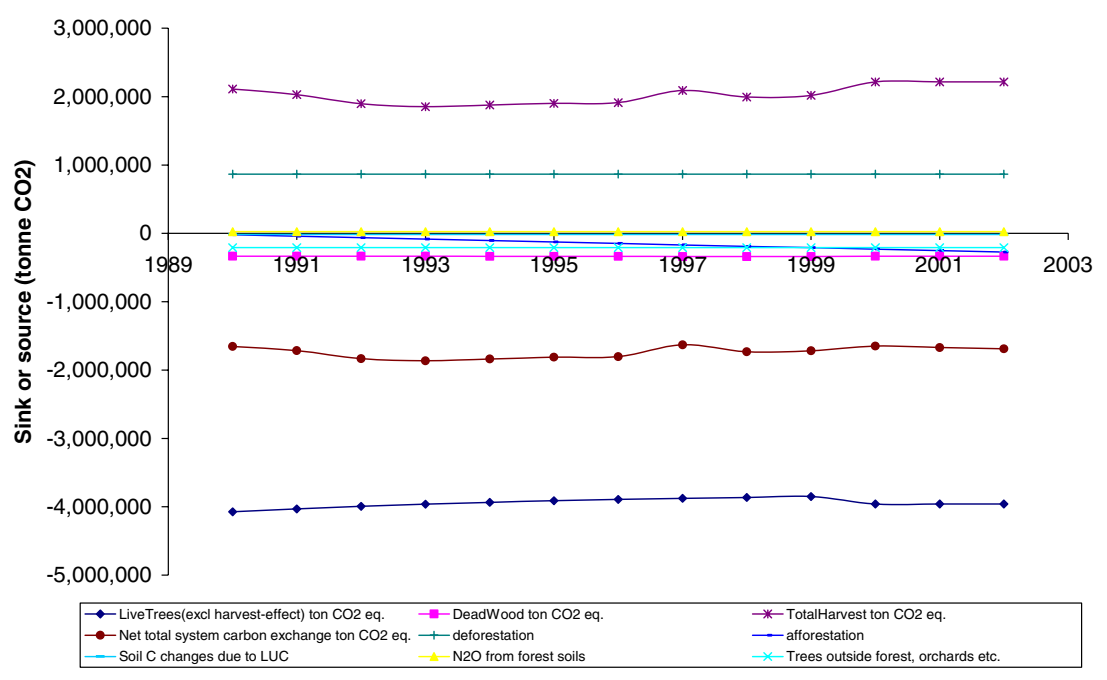

Fig. 5 Temporal development of the components of the forest and other nature terrains carbon balance

Table 5 Comparison of estimates for the Dutch forestry sector C balance

\begin{tabular}{lll}
\hline & $\begin{array}{l}\text { Flux (Million tonnes } \mathrm{CO}_{2} \text { year } \\
\text { (negative is sink) }\end{array}$ & Reference \\
\hline New system & -1.74 & Current study \\
Old system (reporting to UNFCCC) & -1.41 & Klein Goldewijk et al. 2004 \\
Reporting to UN-ECE & -1.47 & UN-ECE/FAO 2000 \\
Static bookkeeping of forest & -1.21 & Nabuurs and Mohren 1993 \\
Whole biosphere (cropland, & 23.8 & Janssens et al. 2004 \\
$\quad$ grassland, peat, forests) & & Karjalainen et al. 2003 \\
\hline Dynamic forestry sector model & -1.5 & \\
\hline
\end{tabular}

1.4 in the old system. This is an average difference of $32 \%$. This difference is rather small because several of the processes that were added to the system compensate each other. The sources from deforestation and $\mathrm{N}_{2} \mathrm{O}$ emissions (around 900 ktonne $\mathrm{CO} 2$ ) are for two thirds compensated by the sinks from afforestation, dead wood, soil $\mathrm{C}$ changes, and trees outside forest. How the $\mathrm{C}$ balance of this system will evolve in coming years is hard to say, and will depend on many activities as harvesting levels, and land use changes.

From Table 5 it appears that most estimates for the Dutch forestry sector are rather close to each other. With exception of the Janssens et al. paper, the highest estimate is 55\% higher than the lowest. Janssens et al. came up with a totally different number for the total Dutch biosphere because of large sources they found for cropland and drained peatlands. All other differences between the estimates of Table 5 can be explained from small differences in pools included or methodological differences.

A further improvement in this system could be sought in application of CO2FIX and CO2LAND. Namely by automating the application of a CO2FIX forest type on each MFV 
inventory plot, the living biomass could be dynamically simulated together with the litter, dead wood, harvesting, and soil organic carbon dynamics. At present, for three out of four of these pools it was (still) assumed that the pool does not change. In an automated dynamic system these pools could be improved significantly, although we realize that for each MFV inventory plot, quite some additional data would be needed. Furthermore, through a combined application of CO2FIX and CO2LAND, the land use changes (some of them Kyoto Lands) which appear very significant in The Netherlands, could be followed in a dynamic way as well.

It is clear however, from the present system that Annex I countries have too often assumed that many carbon pools are neither a source nor a sink. This appears not to be true. When land use changes are taken into account, as well as drainage of peatland, the whole biosphere in an Annex I country often appears to be a net source. The 'Australia' clause in the Kyoto Protocol may thus apply to many more countries than just Australia.

Acknowledgements This research has been funded by the Climate Change Research Programme 421, under project nr. 230986. We wish to thank the Steering Committee (WEB Sinks) for their advice and comments. Furthermore we wish to thank Gerard Dirkse for providing the plot level forest inventory data.

\section{References}

Daamen (1991) Oogst uit eindhak. Projekt houtoogst statistiek en prognose oogstbaar hout. Rapportserie 31. Maatschap Daamen, Schoonderwoerd, Miedema en de Klein

Daamen (1994) Oogst uit dunning. Hosp cyclus 2:1990-1994. rapportserie nr 48 Maatschap Daamen, Schoonderwoerd, Miedema en de Klein

Daamen (1996) Velling en oogst. Hosp cyclus 2:1991-1995. rapportserie nr 63 Maatschap Daamen, Schoonderwoerd en de Klein

Daamen (1997) Velling en oogst. Hosp cyclus 2:1992-1996. rapportserie nr 70. Maatschap Daamen, Schoonderwoerd en de Klein

Daamen (1998) Velling en oogst. Hosp cyclus 2:1993-1997. rapportserie nr 78, Bureau Daamen

Daamen (2000) Velling en oogst. Hosp cyclus 3:1995-1999. rapportserie 2. Bureau Daamen

Diemont WH, Oude Voshaar JH (1994) Effects of climate and management on the productivity of Dutch heathlands. J Appl Ecol 31:709-716

de Groot WJM, Kiestra E, de Vries F, Kuikman PJ (2005) National system of greenhouse gas reporting for land use and land use change: carbon stock changes in The Netherlands due to land use changes 1990-2000. Alterra report 1035-3. Wageningen

van Hees AFM, Clerkx S (1999) De levende natuur [Dead wood in the forest]. (In Dutch)

IPCC (2003) LUCF sector good practice guidance. Penman et al. (eds.), IPCC Good practice Guidance for Land Use, Land Use Change and Forestry. IPCC NGGIP Programme. Published by IGES for IPCC. Japan.

IPCC (2006) 2006 IPCC guidelines for national greenhouse gas inventories - Vol 4: Agriculture, Forestry and Other Land use. Authors: Paustian K et al. Published by the Institute for Global Environmental Strategies (IGES), Hayama, Japan on behalf of the IPCC.

Janssens IA, Freibauer A, Schlamadinger B, Ceulemans R, Ciais P, Dolman AJ, Heimann M, Nabuurs G-J, Smith P, Valentini R, Schulze E-D (2004) The carbon budget of terrestrial ecosystems at country-scale - a European case study. Biogeosci Discuss 1:167-193

Karjalainen T., Pussinen A, Liski J, Nabuurs GJ, Eggers T, Lapvetelainen T, Kaipainen T (2003) Scenario analysis of the impacts of forest management and climate change on the European forest sector carbon budget. Forest Policy Econ 5:141-155

Klein Goldewijk K, Olivier JGJ, Peters JAHW, Coenen PWHG, Vreuls HHJ (2004) Greenhouse gas emissions in The Netherlands 1990-2002. National Inventory Report 2004. Report 773201008/2004. RIVM, Bilthoven

Kramer H, Knol W (2007) Land use in the Netherlands in 1990 and 2000. Alterra rapport in press. Alterra Wageningen

Kuikman P, de Groot W, Hendriks R, Verhagen J, de Vries F (2003) Stocks of C in soils and emissions of $\mathrm{CO}_{2}$ from agricultural soils in The Netherlands. Alterra rapport 561. Wageningen $37 \mathrm{pp}$ 
Kuikman P, Kooistra L, Nabuurs GJ (2004) Land use, agriculture and greenhouse gas emissions in the Netherlands: omissions in the National Inventory Report and potential under Kyoto Protocol article 3.4. Alterra report 903 . Alterra, Wageningen, $60 \mathrm{pp}$

Lindner M, Lucht W, Bouriaud O, Green T, Janssens I, Brumme R, Butterbach-Bahl K, Nabuurs GJ, + 13 other (2004) Specific study on forest greenhouse gas budget. Discussion paper of the GHG Carbo Europe Concerted action, $62 \mathrm{pp}$

Nabuurs GJ, Mohren GMJ (1993) Carbon in Dutch forest ecosystems. Neth J Agr Sci 41:309-326

Nabuurs GJ, Daamen W, Dirkse G, Paasman J, Kuikman P, verhagen J (2003) Present Readiness of, and white spots in the Dutch national System for greenhouse gas reporting of the Land Use, Land Use change and Forestry sector (LULUCF). Alterra report 774. 95 p. Wageningen

Nabuurs GJ, van den Wyngaert IJ, Daamen WD, Helmink ATF, de Groot W, Knol WC, Kramer H, Kuikman P (2005) National System of Greenhouse Gas Reporting for Forest and Nature Areas under UNFCCC in The Netherlands - version 1.0 for 1990-2002. Alterra Report 1112.

Olivier JGJ, Brandes LJ, Peters JAHW, Coenen PWHG, Vreuls HHJ (2003) Greenhouse gas emissions in the Netherlands 1990-2001. National inventory report 2003. RIVM Report 773201 007/2003. Bilthoven

Papen H, Butterbach-Bahl K (1999) A 3-year continuous record of nitrogen trace gas fluxes from untreated and limed soil of a $\mathrm{N}$-saturated spruce and beech forest ecosystem in Germany, $1 \mathrm{~N}_{2} \mathrm{O}$ emissions. $\mathrm{J}$ Geophys Res 104:18487-18503

Pleijter M (2004) Veengronden en moerige gronden op de Bodemkaart van Nederland anno 2003 - Onderzoek naar de afname van het areaal veengronden rondom Schoonebeek. Alterra report 1029 p 39

Spakman J, van Loon MMJ, van der Auwaert RJK, Gielen DJ, Olivier JGJ, Zonneveld EA (1997) Methode voor de berekening van broeikasgasemissies. Publikatiereeks Emissie registratie Nr 37. RIVM, Bilthoven $86 \mathrm{p}$

UN-ECE/FAO (2000) Forest Resources of Europe, CIS, North America, Australia, Japan and New Zealand. Geneva Timber and Forest Study Papers, No 17, $445 \mathrm{p}$

van den Burg J (1999) De O horizont in Nederlandse bossen op de pleistocene zandgronden: resultaten van et onderzoek door "De Dorschkamp" in de periode 1950-1991. IBN report 433.Wageningen. 182 pp

Zianis D, Muukkonen P, Mäkipää R, Mencuccini M (2005) Biomass and stem voluem equations for tree species in Europe. Silva Fennica Monographs 4. 63 pp, based on the COST E21 action. http:// www.efi.fi/coste21/ 